\title{
Characteristics of free cells and aggregated flocs for the flocculation and sedimentation of activated sludge
}

\author{
A. J. $\mathrm{Li}^{1,2} \cdot$ X. Y. $\mathrm{Li}^{2} \cdot$ J. D. Gu ${ }^{3}$
}

Received: 18 March 2015/Revised: 7 September 2015/Accepted: 22 September 2015/Published online: 14 October 2015

(C) Islamic Azad University (IAU) 2015

\begin{abstract}
Laboratory experiments were conducted to investigate the correlation of the free cells/aggregated flocs characteristics and the sludge flocculation and separation behavior during the activated sludge process. Activated sludge was cultured in three laboratory-scale batch reactors with same carbon sources of glucose but different sludge retention times (SRTs) of 5, 10 and 20 days. The variation in the operation condition produced sludge with different flocculation and separation characteristics. The reactor performance in terms of bioflocculation as measured by the amount of suspended solids in the effluent, sludge sedimentation and compression as measured by the sludge value index improved considerably as the SRT lengthened. The higher SRT was related to less negatively charged surface of free cells and more hydrophobic of aggregated flocs. The negative zeta potential of aggregated flocs $(11-13 \mathrm{mV})$ was smaller than that of free cells $(15-23 \mathrm{mV})$, and free cells carrying lesser negative surface charges resulted in effluent clarification. Hydrophobicity of aggregated flocs (10-17\%) in each reactor was higher than
\end{abstract}

Electronic supplementary material The online version of this article (doi:10.1007/s13762-015-0896-9) contains supplementary material, which is available to authorized users.

A. J. Li

liaj@bnu.edu.cn

1 Key Laboratory of Water and Sediment Sciences of the Ministry of Education/State Key Laboratory of Water Environment Simulation, School of Environment, Beijing Normal University, Beijing 100875, China

2 Environmental Engineering Research Centre, Department of Civil Engineering, The University of Hong Kong, Pokfulam Road, Hong Kong, China

3 School of Biological Sciences, The University of Hong Kong, Pokfulam Road, Hong Kong, China that of free cells $(5-8 \%)$. The increase in hydrophobicity of aggregated flocs had positive effect on settleability. Floc strength measured by breakage/erosion index was closely related to hydrophobicity of aggregated flocs, but no correlation could be established with zeta potential of aggregated flocs. In addition, different bacterial species existed in free cells and aggregated flocs. Microbial similarity between free cells and aggregated flocs increased with shorter SRT and was closely related to effluent clarification.

Keywords Free cells · Aggregated flocs · Hydrophobicity · Zeta potential $\cdot$ Microbial community

\section{Introduction}

The activated sludge process is the most common biological wastewater treatment process. Sludge flocculation transforms microbial cells into aggregates via various physical, chemical and biological interactions, which governs the performance of biomass-water separation. Investigating the characteristics of activated sludge and their relationship with system performance may offer useful information for process monitoring and controlling. Separation efficiency is largely affected by the activated sludge structure in terms of the particle size distribution of the flocs. The particle size distribution of activated sludge is bimodal, containing two classes, i.e., aggregated flocs $(25-100 \mu \mathrm{m})$ and free cells $(\leq 5 \mu \mathrm{m})(\mathrm{Li}$ and Ganczarczyk 1991; Mikkelsen and Kelding 2002). Aggregated flocs consist of a multitude of bacteria and extracellular polymeric substance. Free cells are to large extent single bacteria, but may contain some colloidal matter. Aggregated flocs are the main constituents of 
sludge by volume and mass. Although the free cells only contribute with a small fraction of the total sludge mass in activated sludge, their impact on solid/liquid separation is critical. Due to their small size, they are a source of supernatant turbidity. Therefore, they both have significant impact on clarification and the relative magnitude and different property of the two classes are important quantities for solid-liquid separation (Mikkelsen and Kelding 2002). However, no systematic investigation into the physicochemical and biological properties of free cells and aggregated flocs for activated sludge system performance is available so far.

Microbial cells and sludge flocs carry negative charges due to the ionization of the anionic functional groups, such as carboxylic and phosphate. These properties may be characterized by zeta potential or surface charge, which is widely recognized as a vital factor governing the stability of bioaggregates and directly affects the sludge flocculability and settleability (Alibhai and Forstera 1986; Liao et al. 2001; Sheng and Yu 2006), although zeta potential has been found to be indecisive in drinking-water flocculation using hydrolysable metal salts (Xiao et al. 2008). Surface hydrophobicity refers to the propensity of microbial cells being repelled from a mass of water and was shown to be an important factor that determined the relative bacterial adhesion and sludge compression potential (Olofsson et al. 1998). Besides, microbial community is one of the most important factors that cause different performances in activated sludge process (Bura et al. 1998). Thus, it is very essential to study the zeta potential, hydrophobicity and microbial community of free cells and aggregated flocs and its correlation with solid-liquid separation performances.

Some researches indicated that the variation in the activated sludge process conditions in terms of sludge retention time (SRT) resulted in different performances in organic degradation and sludge-effluent separation (Bura et al. 1998; Li and Yang 2007). In this laboratory study (Hong Kong 2007), three batch reactors were operated under different SRT conditions to grow activated sludge with different treatment and solid-liquid separation performances. Free cells and aggregated flocs were collected, respectively, from activated sludge after an optimal period of settling. The goal of this research was to examine the zeta potential, hydrophobicity and microbial community of free cells in activated sludge supernatant and aggregated flocs in activated sludge systems, to correlate the free cells/aggregated flocs characteristics and the sludge flocculation and separation behavior, and to determine the respective effects of free cells and aggregated flocs on the sludge structure, flocculation and sedimentation properties.

\section{Materials and methods}

\section{Setup of activated sludge reactors}

Three 2-1 beakers with a working volume of 1.5 liter each were used to cultivate activated sludge and were placed in parallel on a paddle mixer (PB-700, Phipps \& Bird). The configuration and operation of activated sludge process have been previously described ( $\mathrm{Li}$ and Yuan 2002; Li and Leung 2005). In brief, activated sludge from a full-scale sewage treatment plant (Stanley Sewage Treatment Works, Hong Kong) was used as the seed sludge. The reactors were fed once a day with synthetic wastewater that contained glucose, urea, potassium phosphate and other inorganic salts to keep the chemical oxygen demand (COD)/N/P ratio at 100:5:1. Different SRTs of 5, 10 and 20 days were used for the three reactors through controlling different sludge discharge ratios. Three different organic loading rates- $1.65,1.0,0.55 \mathrm{~g}$ $\mathrm{COD} / \mathrm{l} \mathrm{d}$-were used for three sequencing batch reactors (SBRs) (G5, G10 and G20) respectively, resulting in similar biomass concentration among three SBRs. The reactors were operated at room temperature, and water temperature was $20-22{ }^{\circ} \mathrm{C} . \mathrm{NaHCO}_{3}$ was dosed into the feeding solution to maintain the reactor $\mathrm{pH}$ in the range of 7.0-8.5.

\section{Zeta potential and hydrophobicity of free cells and aggregated flocs}

Sludge samples were collected from the reactors before daily feeding. After $15 \mathrm{~min}$ of sedimentation, the supernatant was collected for free cell analysis. The settling part was collected and then sheared by a vortex mixer for $5 \mathrm{~min}$ to become suspended cells for aggregated floc analysis. The zeta potential of the bacterial cells was determined by diluting the rinsed cell pellet in a phosphate urea magnesium sulfate (PUM) electrolyte solution with no $\mathrm{pH}$ adjustment (pH 7.7). The PUM solution (PUM1) was prepared with $\mathrm{K}_{2} \mathrm{HPO}_{4} \cdot 3 \mathrm{H}_{2} \mathrm{O}(1.11 \mathrm{~g}), \mathrm{KH}_{2} \mathrm{PO}_{4}(0.363 \mathrm{~g})$, urea $(0.09 \mathrm{~g})$, $\mathrm{MgSO}_{4} \cdot 7 \mathrm{H}_{2} \mathrm{O}(0.01 \mathrm{~g})$ diluted in 1 liter distilled water. Zeta potential measurements were conducted at $25{ }^{\circ} \mathrm{C}$ using a zeta potential analyzer (Delsa 440SX, Coulter) and were repeated a minimum of three times at each ionic strength with freshly rinsed cells. All reagents were purchased from Sigma-Aldrich (HK, China).

Of the methods available for measuring surface hydrophobicity, the simplest, and in many ways the most appropriate for plant sample, is the microbial adherence to hydrocarbons (MATH) assay (Boyette et al. 2001). Free cells and aggregated flocs were harvested, respectively, by centrifugation at $3500 \mathrm{rpm}$ for $15 \mathrm{~min}$ and then washed twice with PUM buffer (PUM2) which contained $\mathrm{K}_{2}$ $\mathrm{HPO}_{4} \cdot 3 \mathrm{H}_{2} \mathrm{O}(22.2 \mathrm{~g} / \mathrm{l}), \mathrm{KH}_{2} \mathrm{PO}_{4}(7.26 \mathrm{~g} / \mathrm{l})$, urea $(1.8 \mathrm{~g} / \mathrm{l})$ 
and $\mathrm{MgSO}_{4} \cdot 7 \mathrm{H}_{2} \mathrm{O}(0.2 \mathrm{~g} / \mathrm{l})$ (Rosenberg et al. 1980). After that, the pellets were resuspended in the same buffer to give the turbidity. Then $5 \mathrm{ml}$ of hexadecane was added to $20 \mathrm{ml}$ aliquot of this suspension. The two phases were incubated for $15 \mathrm{~min}$ at $30^{\circ} \mathrm{C}$ and then mixed by a vortex for $1 \mathrm{~min}$. The mixture was then placed for $30 \mathrm{~min}$, and the turbidity of the sludge suspension in water phase was measured again. The percentage hydrophobicity can then be calculated as followed

$$
\begin{aligned}
& \text { Hydrophobicity } \\
& \quad=100 \frac{\text { Turbidity of intial soln - Turbidity of final soln }}{\text { Turbidity of intial soln }}
\end{aligned}
$$

\section{Shear sensitivity of aggregated flocs}

Activated sludge may flocculate under low turbulence levels and break up when exposed to high turbulence. A population of particles in water can be described with a continuous size distribution. Breakage of the particle flocs by enhanced turbulence (e.g., vortex) can transform large flocs into smaller particles and hence alter the particle size distribution (PSD). Breakup occurs by two mechanisms of differing nature. Fragmentation of flocs into flocs fragments causes a shift toward smaller flocs. Assuming the corresponding mean size distribution of the aggregated flocs before breakage as $D_{\text {original }}$ and after breakage as $D_{\text {final }}$, the breakage index can be defined and written as

Breakage index $=\frac{D_{\text {original }}}{D_{\text {final }}}$

Erosion of free cells from aggregated floc surfaces on the other hand causes a shift in the relative mass of the two size classes. Assuming the corresponding size distribution $(\leq 5 \mu \mathrm{m})$ (Mikkelsen et al. 2002) of free cells before erosion as $d_{\text {original }}$ and after erosion as $d_{\text {final }}$, the erosion index can be defined and written as

Erosion index $=\frac{d_{\text {original }}}{d_{\text {final }}}$

Aggregated flocs were collected and then sheared by a vortex mixer for $5 \mathrm{~min}$ for breakage and erosion analysis. PSD and the corresponding mean size distribution of the sludge flocs were measured by a laser diffraction particle size analyzer (LS13 320, Beckman Coulter, Fullerton, CA, USA).

\section{Extraction of DNA, polymerase chain reaction (PCR) and denaturing gradient gel electrophoresis (DGGE)}

DGGE band profiles are used to reveal the most abundant DNA types among the species in a microbial community, and DGGE analysis has been used as a tool to monitor changes in the structure of a microbial community in a bioreactor (Eichner et al. 1999). In this experiment, the genomic DNA of the sludge samples was extracted following the protocol described by Zhuang et al. (2005) using a beadbeater (Mini-beadbeaterTM, Biospec, Bartlesville, OK, USA) and a microcentrifuge (MiniSpin plus $^{\circledR}$, Eppendorf, Hamburg, Germany). Subsequently, the variable V3 region of the bacterial 16S rDNA gene sequence (corresponding to positions 341-534 of E. coli sequence) was amplified by PCR (Muyzer et al. 1993). The GC-binded $338 \mathrm{~F}$ primer sequence was $5^{\prime}$-CGCCCGCCG CGCGCGGCGGGCGGGGCGGGGGCACGGGGGGCCT ACGGGAGGCAGCAG- $3^{\prime}$, and the 518R primer was $5^{\prime}$ ATTACCGCGGCTGCTGG-3'. PCR amplification was performed with a DNA Engine ${ }^{\circledR}$ Peltier Thermal Cycler (PTC-200, MJ Research, Waltham, MA, USA). A touchdown thermal profile technique was used for the PCR procedure (Watanabe et al. 1998). The PCR-amplified DNA products were separated by DGGE, and the DGGE images were acquired using the ChemiDoc (Bio-Rad, Hercules, CA, USA) gel documentation system following the procedures described previously ( $\mathrm{Li}$ et al. 2008). Quantity One software (Bio-Rad) was used for band pattern analysis. Dendrograms that related the banding pattern similarities between different DGGE profiles were calculated by the un-weighted pair group method for the arithmetic means (UPGMA) using the MultiVariate Statistical Package (MVSP) software.

\section{Analytical methods}

Sludge and effluent samples were collected from the reactors before daily feeding. The sludge mixed liquor suspended solids (MLSS) were measured according to the standard methods (APHA 2005). The supernatant was collected after 30 min of sedimentation and measured for determining the effluent suspended solids (ESS). The ESS level demonstrates the performance of sludge flocculation and effluent clarification. The sludge value index (SVI) value of the sludge mixture was employed to evaluate the settleability and compressibility of sludge sample, which is measured with a 100-ml cylinder after $30 \mathrm{~min}$ of settlement.

\section{Results and discussion}

\section{The quantity of zeta potential and hydrophobicity for free cells and aggregated flocs}

As indicated by the measured zeta potentials (Fig. 1a), the bacteria of free cells and aggregated flocs both were 


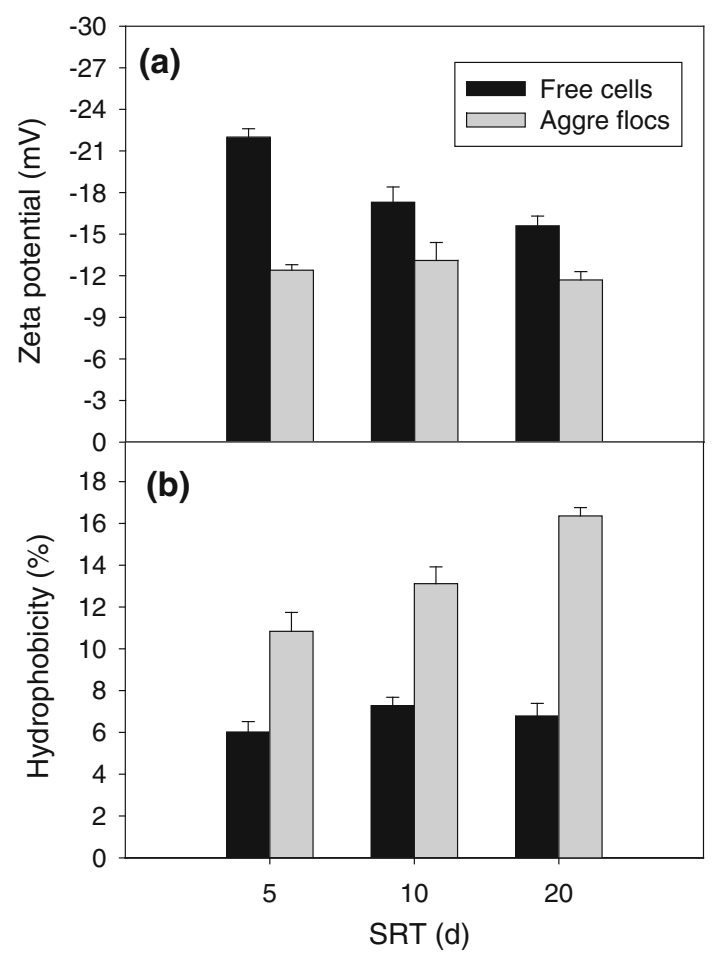

Fig. 1 Quantities of zeta potential and hydrophobicity for free cells and aggregated flocs

apparently negatively charged, mostly within the range of -11 to $-23 \mathrm{mV}$ under $\mathrm{pH}$ 7.7. The negative zeta potential of free cells decreased as the SRT increased for the glucose-fed sludge, which is in agreement with previous findings ( $\mathrm{Li}$ and Yang 2007). However, the negative zeta potential of aggregated flocs maintained around $12 \mathrm{mV}$ as the SRT increased and was smaller than that of free cells. Extracellular polymeric substance (EPS) is always considered to be able to influence the surface physicochemical properties (e.g., surface charge, hydrophobicity). The origin of EPS is very complicated. The components and content of EPS heavily depend on many factors such as bacterial type and cultivation time. The relationship between the EPS content and surface characteristics of microorganisms from various origins has been reported (Liao et al. 2001; Li and Yang 2007; Fang et al. 2015). However, contrary results were always obtained and they seemed to be greatly related to their origins and growth phases. Besides, surface charge of free cells almost has nothing to do with EPS due to low EPS content in free cells. It is possible that different SRT operation affected the bacterial communities of free cells, which resulted in different zeta potential.

Hydrophobicity of aggregated flocs $(10-17 \%)$ in each reactor was higher than that of free cells $(5-8 \%)$, and hydrophobicity almost increased with an increasing SRT for aggregated flocs (Fig. 1b). It has been reported that sludge hydrophobicity increased with SRT not just in full- scale municipal wastewater treatment plant (Frølund et al. 1994), but also in laboratory-scale SBR (Bura et al. 1998). Some study found that cells grown in stationary phase were more hydrophobic than those grown in exponential phase (Sheng and Yu 2006); this implies that sludge hydrophobicity increase with SRT. The production of EPS was closely associated with the cell growth. At the stationary phase or long SRT, cells produced less EPS than that at the exponential phase or short SRT. The surface would become more hydrophobic as the EPS decrease, because the content of EPS had a negative effect on the relative hydrophobicity (Wilen et al. 2003).

This result indicated that there was a significant difference in the surface charge and hydrophobicity at different SRT. It has been reported that the better flocculation ability of sludge at higher SRT was related to a more hydrophobic and less negatively charged surface (Bura et al. 1998; Sheng et al. 2006). Furthermore, the higher SRT was related to a more hydrophobic of aggregated flocs and less negatively charged surface of free cells.

\section{Effect of zeta potential of free cells on biomass flocculation and effluent clarification}

Although zeta potential has been found indecisive in drinking-water flocculation using hydrolysable metal salts (Xiao et al. 2008), the surface charge has long been believed to be important in controlling the stability of microbial aggregates. Bacteria may carry net negative surface charge when cultivated at physiological $\mathrm{pH}$ values. According to the well-known DLVO theory, when two surfaces have a charge of the same sign, there is a repulsive force to prevent the approach of one cell to another. Free cells with higher SRT have lesser negative surface charges than free cells with low SRT. The former have zeta potential below $-15 \mathrm{mV}$, and the latter had zeta potential round $-23 \mathrm{mV}$. However, surface charges of aggregated flocs for different SRT arranged from -11 to $-13 \mathrm{mV}$ and have no clear differences (Fig. 1a). The experimental data indicate a positive correlation $\left(R^{2}=0.99\right)$ between the amount of SS in the effluent and the zeta potential of free cells (Fig. 2a). The amount of ESS noticeably increased with a larger negative zeta potential of free cells. In contrast, no correlation could be found between the ESS and the zeta potential of aggregated flocs $\left(R^{2}=0.02\right)$ (Fig. 2b). Considering different MLSS in reactors, the relationships between the ratios of ESS to MLSS and negative zeta potential of free cells also have the same trend (Fig. 2c). It has been reported that activated sludge carrying lesser negative surface charges produces an effluent of lower turbidity (Bura et al. 1998). Therefore, it was reasonable to suppose that free cells carrying lesser negative surface charges result in effluent clarification. 
Fig. 2 Effect of zeta potential of free cells and aggregated flocs on biomass flocculation and effluent clarification as indicated by ESS and ESS/ MLSS

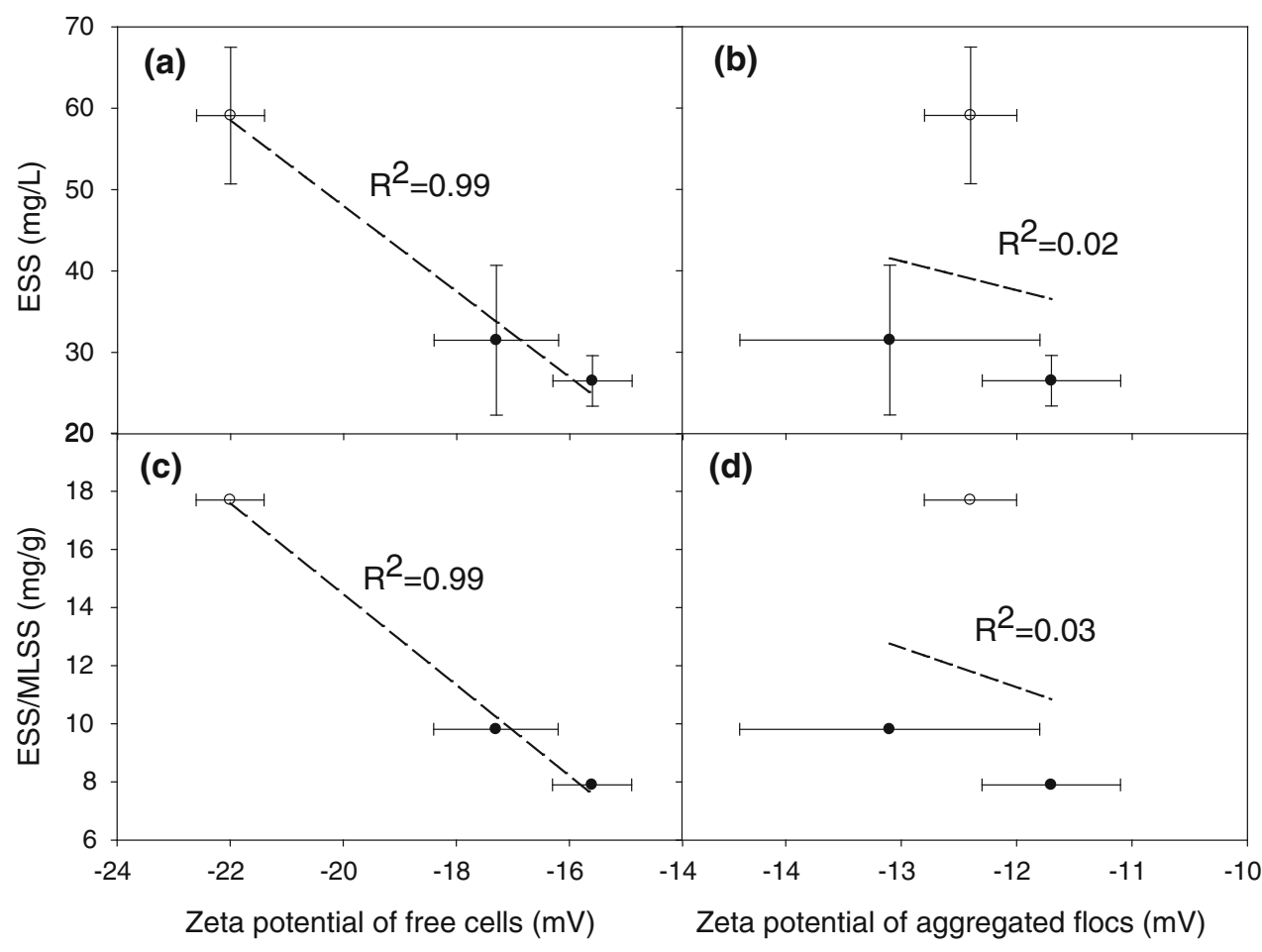

\section{Influence of hydrophobicity of aggregated flocs on sludge settleability and compressibility}

The experimental data in this study indicated a significant correlation $\left(R^{2}=0.92\right)$ between hydrophobicity of aggregated flocs and SVI (Fig. 3a). In contrast, the hydrophobicity of free cells had no linear correlation with SVI ( $\left.R^{2}=0.56\right)$ (Fig. 3b). SVI decreased with increasing hydrophobicity of aggregated flocs instead of that of free cells. Some researchers concluded that the reduction in negative surface charge was not the sole mechanism in bioflocculation (Liu and Fang 2003). Hydrophobic interaction among microbial cells is crucial to the floc formation and sludge settling. It has been reported that increased hydrophobicity generally leads to a better flocculation (Bura et al. 1998). Thus, it is reasonable to suppose the increase in hydrophobicity of aggregated flocs had positive effect on settleability of activated sludge.

\section{Effect of hydrophobicity of aggregated flocs on floc strength}

The stability of flocs in suspension is dependent upon how easy they are to break with aggregate breakage being directly related to the strength and number of the bonds holding the floc together. Floc strength is dependent upon the inter-particle bonds between the components of the aggregate (Bache et al. 1997). A floc will break if the stress applied at its surface is larger than the bonding strength within the floc (Boller and Blaser 1998). The hydrophobicity of aggregated flocs also showed a significant effect on floc strength measured by breakage index and erosion
Fig. 3 Effect of hydrophobicity of free cells and aggregated flocs on sludge settleability and compressibility as measured by SVI

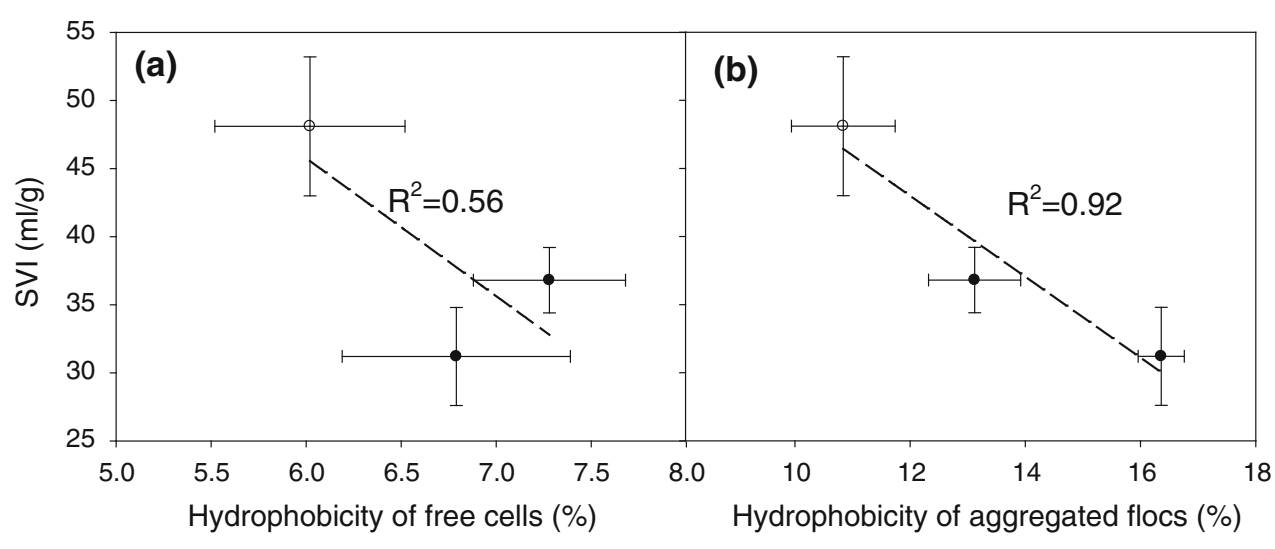


Fig. 4 Relationships between floc strength and hydrophobicity/zeta potential of aggregated flocs

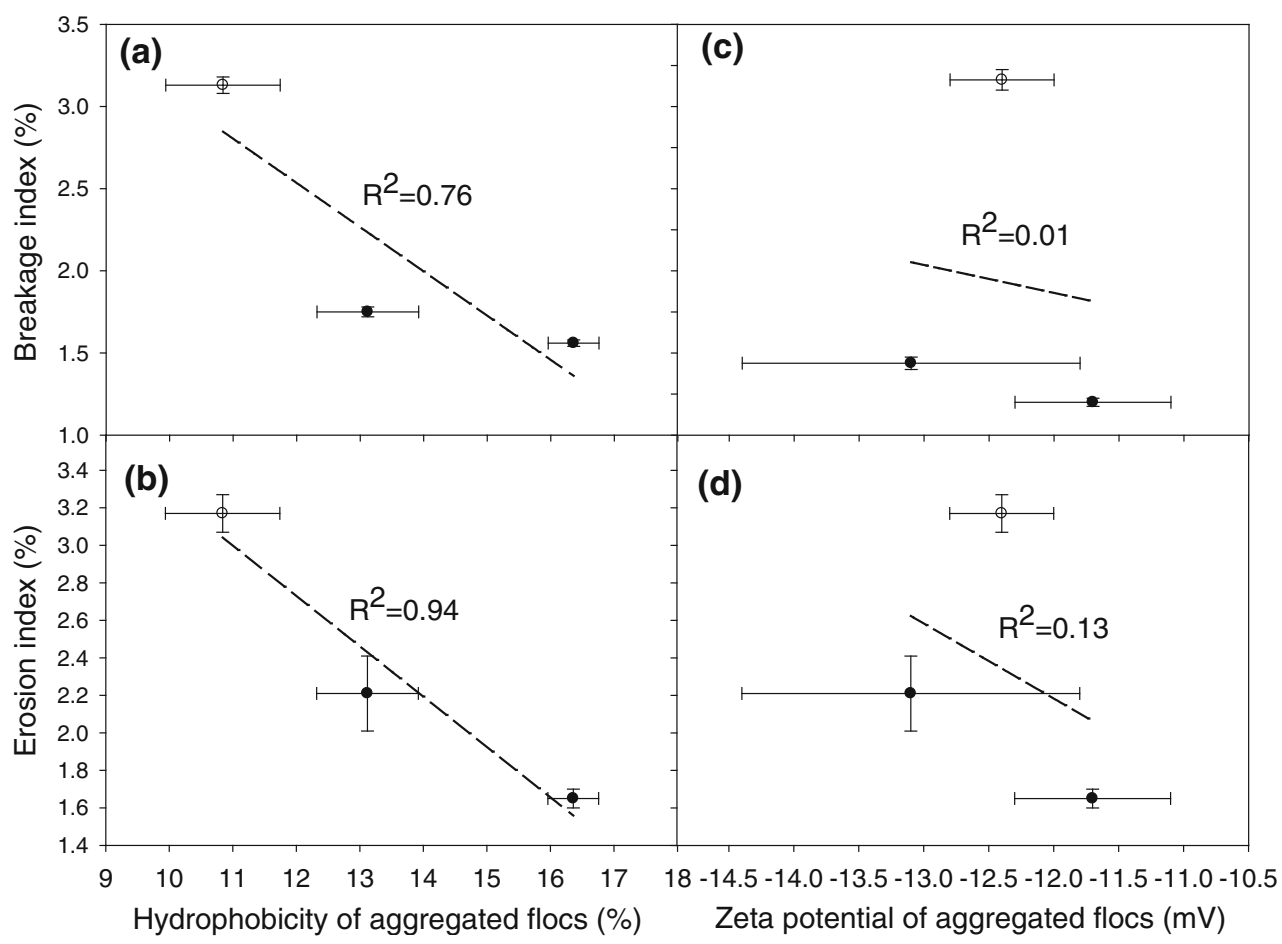

index (Fig. 4a, b). However, no correlation could be found between the zeta potential of aggregated flocs and floc strength, both shown as breakage index and erosion index (Fig. 4c, d). The linear correlation between the hydrophobicity of aggregated flocs and erosion index $\left(R^{2}=0.94\right)$ was much higher than that between the hydrophobicity of aggregated flocs and breakage index $\left(R^{2}=0.76\right)$. As noted by Gregory, most methods for evaluating floc strength have dealt only with the change in floc size in response to hydraulic forces with very little attention given to the free cell concentration (Gregory 1989). In addition, erosion implies a pronounced increase in the free cell population in highly flocculated systems, whereas the relative change in floc size and mass may be minor. Thus, it can be argued that strength of flocs in terms of ability to resist erosion is relevant in solid/liquid separation processes more than that of breakage.

\section{Biodiversity of the free cell and aggregated cell}

Well-resolved DGGE bands were obtained for the biomass of free cells and aggregated flocs in all three reactors (Fig. 5). In a mixture of extracted DNA, less abundant sequences may not be amplified sufficiently to form visible DGGE bands (Eichner et al. 1999; Li et al. 2008). For the three different reactors under different SRT conditions, the bacterial populations were different producing different DGGE bands and patterns. The bacterial richness of G20 reactor is higher than that of G10 and G5 reactors, which indicated that long SRT operation led to high microbial

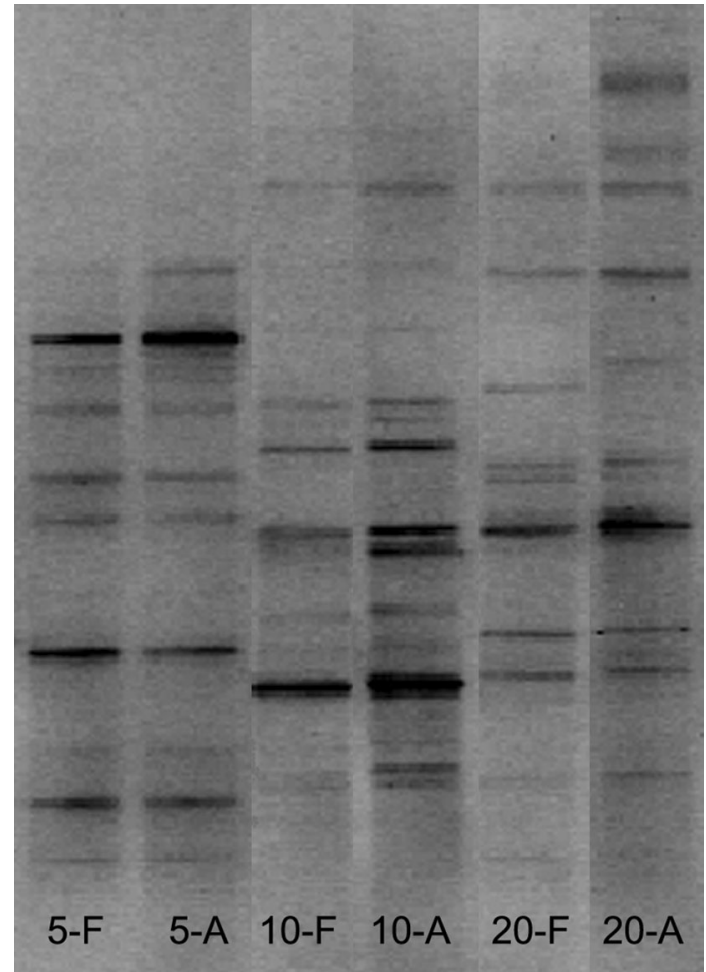

Fig. 5 DGGE profiles of bacterial community of free cells and aggregated flocs in three different SRT reactors [n-F: free cells from reactor $\mathrm{n}(\mathrm{G} 5, \mathrm{G} 10$ or G20), n-A: aggregated flocs from reactor $\mathrm{n}(\mathrm{G} 5$, G10 or G20)]

diversity. Besides, bacterial community of free cells was different from that of aggregated cells in each reactor, which suggested that bioflocculation and settling 


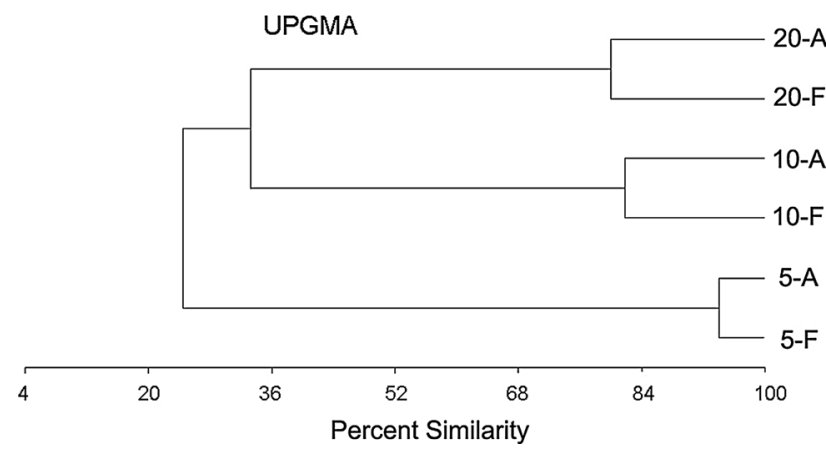

Fig. 6 Complete linkage analysis dendrogram of DGGE fingerprints (unweighted band)

performance of activated sludge possibly related to the bacterial community. Diversity of free cells was lower than that of aggregated flocs.

Generally, analyses of these patterns are based on unweighted bands and weighted bands, respectively. When band weighting is applied in the analyses, the resolution especially between lower-similarity clusters is lost, with additional clusters branching at $0 \%$ similarity. Largely for this empirical reason, but also because of the limitations of PCR amplification of unknown populations (Becker et al. 2000; Farrelly et al. 1995; Polz and Cavanaugh 1998), band weighting was not used for the similarity analyses. Since at any given time point there would be different populations of target DNAs, the relative amplification efficiency of each target could change. This means that equal proportions of a given target in different samples might be amplified to a different degree and that final proportions of PCR-amplified fragments would not correspond to the initial proportions of the PCR target. In fact, DNA clone frequency and DGGE band intensity have been found not to be in agreement (LaPara et al. 2000). Therefore, dendrograms based on unweighted band are in more agreement with the operated conditions than that based on weighted band. Based on unweighted bands, banding pattern similarity is analyzed by applying the complete linkage (Fig. 6) algorithms. The complete linkage algorithm is good for identifying outlier clusters and showed six groups with intragroup similarity at approximately 80-94\% and intergroup similarity at about $30 \%$. The microbial similarity between free cells and aggregated flocs was 94,82 and $80 \%$ for G5, G10 and G20, respectively. The microbial similarity between free cells and aggregated flocs increased with the shorter SRT operation. Besides, banding pattern of G10 was prior to cluster with that of G20 compared with G5, which indicated that microbial structure of G10 was more similar with that of G20 instead of G5.

\section{Conclusion}

The variation in SRT produced activated sludge samples with different hydrophobicity, surface charge, flocs strength and microbial community. Higher SRT resulted in a less negatively charged surface of free cells and more hydrophobic of aggregated flocs. Free cells carrying lesser negative surface charges resulted in effluent clarification as well as the increase in hydrophobicity of aggregated flocs could affect settleability positively. Floc strength measured by breakage index and erosion index was closely related to sludge hydrophobicity instead of sludge surface charge. No matter operated under SRT of 5, 10 or 20 days, the free cells and the aggregated flocs have different microbial population. And the microbial similarity between free cells and aggregated flocs increased along with the SRT decreased.

Acknowledgments This research was supported by the Natural Science Foundation of China (No. 51208038), the Research Grants Council (No. HKU714811E) and the University Grants Committee (UGC) of the Hong Kong SAR Government (No. SEG_HKU10).

\section{References}

Alibhai KRK, Forstera CF (1986) Physicochemical and biological characteristics of sludges produced in anaerobic upflow sludge blanket reactors. Enzyme Microb Technol 8:601-606

APHA (2005) Standard methods for the examination of water and wastewater, 21st edn. American Public Health Administration, Washington, DC

Bache DH, Johnson C, McGilligan JF, Rasool E (1997) A conceptual view of floc structure in the sweep floc domain. Water Sci Technol 36:49-56

Becker S, Boger P, Oehlmann R, Ernst A (2000) PCR bias in ecological analysis: a case study for quantitative Taq nuclease assays in analyses of microbial communities. Appl Environ Microbiol 66:4945-4953

Boller M, Blaser S (1998) Particles under stress. Water Sci Technol 37:9-29

Boyette S, Lovett J, Gaboda W, Soares J (2001) Cell surface and exopolymer characterization of laboratory stabilized activated sludge from a beverage bottling plant. Water Sci Technol 43:175-184

Bura R, Cheung M, Liao B, Finlayson J, Lee BC, Droppo IG, Leppard GG, Liss SN (1998) Composition of extracellular polymeric substances in the activated sludge floc matrix. Water Sci Technol 37:325-333

Eichner CA, Erb RW, Timmis KN, Wagner-Döbler I (1999) Thermal gradient gel electrophoresis analysis of bioprotection from pollutant shocks in the activated sludge microbial community. Appl Environ Microbiol 65:102-109

Fang W, Zhang PY, Ye J, Wu Y, Zhang HB, Liu JB, Zhu Y, Zeng GM (2015) Physicochemical properties of sewage sludge disintegrated with high pressure homogenization. Int Biodeterior Biodegrad 102:126-130

Farrelly V, Rainey FA, Stackebrandt E (1995) Effect of genome size and rrn gene copy number on PCR amplification of 16S rRNA 
genes from a mixture of bacterial species. Appl Environ Microbiol 61:2798-2801

Frølund B, Keiding K, Neielsen P (1994) A comparative study of biopolymers from a conventional and advanced activated sludge treatment plant. Water Sci Technol 29:137-141

Gregory J (1989) Fundamentals of flocculation. Crit Rev Environ Control 19:185-230

LaPara TM, Nakatsu CH, Pantea L, Alleman JE (2000) Phylogenetic analysis of bacterial communities in mesophilic and thermophilic bioreactors treating pharmaceutical wastewater. Appl Environ Microbiol 66:3951-3959

Li D, Ganczarczyk J (1991) Size distribution of activated sludge flocs. Res J WPCF 63:806-814

Li XY, Leung RPC (2005) Determination of the fractal dimension of microbial flocs from the change in their size distribution after breakage. Environ Sci Technol 39:2731-2735

Li XY, Yang SF (2007) Influence of loosely bound extracellular polymeric substances (EPS) on the flocculation, sedimentation and dewaterability of activated sludge. Water Res 41:1022-1030

Li XY, Yuan Y (2002) Collision frequencies of microbial aggregates with small particles by differential sedimentation. Environ Sci Technol 36:387-393

Li AJ, Yang SF, Li XY, Gu JD (2008) Microbial population dynamics during aerobic sludge granulation at different organic loading rates. Water Res 42:3552-3560

Liao BQ, Allen DG, Droppo IG, Leppard GG, Liss SN (2001) Surface properties of sludge and their role in bioflocculation and settleability. Water Res 35:339-350

Liu Y, Fang HHP (2003) Influences of extracellular polymeric substances (EPS) on flocculation, settling, and dewatering of activated sludge. Crit Rev Environ Sci Technol 33:237-273

Mikkelsen LH, Kelding K (2002) The shear sensitivity of activated sludge: an evaluation of the possibility for a standardised floc strength test. Water Res 36:2931-2940
Mikkelsen LH, Mascarenhas T, Nielsen PH (2002) Key parameters in sludge dewatering: testing for the shear sensitivity and EPS content. Water Sci Technol 46:105-114

Muyzer G, de Waal EC, Uitterlinden AG (1993) Profiling of complex microbial populations by denaturing gradient gel electrophoresis analysis of polymerase chain reaction-amplified genes coding for 16S rRNA. Appl Environ Microbiol 59:695-700

Olofsson AC, Zita A, Hermansson M (1998) Floc stability and adhesion of green-fluorescent-protein-marked bacteria to flocs in activated sludge. Microbiology 144:519-528

Polz MF, Cavanaugh CM (1998) Bias in template-to-product ratios in multitemplate PCR. Appl Environ Microbiol 64:3724-3730

Rosenberg M, Gutnick D, Rosenberg E (1980) Adherence of bacteria to hydrocarbons: a simple method for measuring cell-surface hydrophobicity. FEMS Microbiol Lett 9:29-33

Sheng GP, Yu HQ (2006) Relationship between the extracellular polymeric substances and surface characteristics of Rhodopseudomonas acidophila. Appl Microbiol Biotechnol 72:126-131

Sheng GP, Yu HQ, Li XY (2006) Stability of sludge flocs under shear conditions: roles of extracellular polymeric substances (EPS). Biotechnol Bioeng 93:1095-1102

Watanabe K, Teramoto M, Futamata H, Harayama S (1998) Molecular detection, isolation, and physiological characterization of functionally dominant phenol-degrading bacteria in activated sludge. Appl Environ Microbiol 64:4396-4402

Wilen BM, Jin B, Lant P (2003) The influence of key chemical constituents in activated sludge on surface and flocculating properties. Water Res 37:2127-2139

Xiao F, Zhang XR, Lee C (2008) Is electrophoretic mobility determination meaningful for aluminum(III) coagulation of kaolinite suspension? J Colloid Interface Sci 327:348-353

Zhuang WQ, Tay JH, Yi S, Tay STL (2005) Microbial adaptation to biodegradation of tert-butyl alcohol in a sequencing batch reactor. J Biotechnol 118:45-53 